\title{
Commentary 1 to the Manifesto for the Marine Social Sciences: fisheries
}

\author{
Nathalie A. Steins ${ }^{1}$ • Hilde M. Toonen ${ }^{2}$ - Alyne E. Delaney ${ }^{3,4}$ \\ Published online: 3 July 2020 \\ (C) The Author(s) 2020
}

Fisheries have long dominated the agenda of marine social sciences. For most of the twentieth century, studies tended to focus on ethnographies of fishing communities and case studies of local management, and often located in the Global South. Research activities were fragmented, remained academic, and had little impact on policy (Symes et al. 2019). The last 25 years witnessed changes, with increasing focus on fisheries management studies in the Global North, and a growing, yet sometimes hesitant, recognition from policy-makers that social sciences have an important role to play in showing interactions between marine policies on the one hand and fishers' behaviour, compliance, communities and heritage on the other (Symes and Hoefnagel 2010; Urquhart et al. 2011). At the same time, significant changes are taking place in terms of marine use, with coastal and offshore waters no longer being the exclusive domain of fishers. Nature conservation and development, land reclamation, tourism, aquaculture, shipping, mineral extraction and, more recently, renewable energy production particularly through offshore wind farms are putting increasing stress on the oceans, on traditional users and on governance. So does climate change. Considering the current focus on Blue Growth or the Blue Economy (Arbo et al. 2018; Mulazzani and Malorgio

Nathalie A. Steins

nathalie.steins@wur.nl

Hilde M. Toonen

hilde.toonen@wur.nl

Alyne E. Delaney

ad@ifm.aau.dk

1 Wageningen Marine Research, Wageningen University and Research, PO Box 68, 1970 AB IJmuiden, The Netherlands

2 Environmental Policy Group, Wageningen University and Research, Hollandseweg 1, 6677 PC Wageningen, The Netherlands

3 CNEAS, Tohoku University, Sendai, Japan

4 Centre for Blue Governance, Aalborg University, Rendsburggade 14, 9000 Aalborg, Denmark
2017), we fully concur with the Manifesto's statement that marine social science should go beyond fisheries (MMSS 1.1.4). Nevertheless, there still seems to be a bias towards fisheries social science, with one full paragraph dedicated to fisheries (MMSS 1.2) and fisheries also receiving special attention in the section on governance (MMSS 2). This suggests - and we concur - that fisheries remain an important topic for the marine social science agenda, with a broad scope of themes.

Social scientists should continue studying fisheries in relation to 'traditional topics' such as their contribution in shaping identities of individuals and communities, resilience, livelihoods, heritage, resilient coastal communities, and formal and informal governance systems. They should also focus on lesser studied topics, such as the role of women, food security related to fisheries, impacts of market-based approaches, the (future) role of family businesses, fisheries and marine spatial planning, and fishing and climate change, as suggested in the Manifesto (MMSS 1.2; 2.2). Additional topics, some of which have also been suggested in marine social science research agendas (Arbo et al. 2018; Symes and Hoefnagel 2010; Urquhart et al. 2011), we suggest are the following: the impacts of increasing 'industrialisation' of coastal and offshore waters on fisheries, which is particularly relevant in view of the global blue economy agenda where fisheries seem to be losing out (Arbo et al. 2018; Barbesgaard 2018; Bavinck et al. 2017; Jentoft and Knol 2014); development of participative fisheries and ecosystembased governance approaches, including co-production of knowledge (Arbo et al. 2018; Kraan et al. 2014; Röckmann et al. 2015; Stange 2017; Steins et al. 2019; Stephenson et al. 2016; Symes and Hoefnagel 2010; Urquhart et al. 2011); interactions between fisheries of different scales and between regions (Hegland et al. 2012; Sievanen et al. 2013); labour rights including slavery (Marschke and Vandergeest 2016); enhancing an interdisciplinary understanding of fisher or fishing behaviour (Schadeberg et al. 2019; Van Helmond et al. 2016); and the consequences of increased use of advanced technologies in monitoring, control and surveillance on governance and fisher behaviour (Toonen and Bush 2018; Van Helmond et al. 2019). 
In studying fisheries from a social science perspective, we should also address the dichotomy between small scale and large scale, or artisanal and industrial, and the tendency in the social sciences to focus on the former (Steins 2006). This bias is again emphasized in the Manifesto, which calls for supportive research for small-scale fisheries as they comprise 'the largest category of maritime workers', and which advocates that 'their traditional tenure and access rights should be legally protected' (MMSS 2.2.2). We consider this problematic for two reasons.

First, the call for legal protection of the rights of small-scale fisheries in the Manifesto reflects more a political stance rather than suggesting topics for scientific inquiry. For a long time, policy-makers in for example the European Union were reluctant to engage with fisheries social scientists as they were considered to be too political; only by the beginning of the twenty-first century policy-makers came to understand the breadth of social sciences and their potential in relation to fisheries governance (Symes et al. 2019). More than ever, the challenges facing fisheries (and other marine users) require involvement from social scientists as part of interdisciplinary marine research and management advice. Being seen as 'advocates' pressing the case for one particular group or outcome is likely to damage the still fragile position the social sciences have in this context (Rice 2011).

Second, while small-scale fisheries may provide livelihoods for the majority of workers in the maritime sector, the bulk of global fish catch comes from larger scale fisheries (cf. Commentary 8). These fisheries have an important role in our global seafood system and, if not governed well, have major impacts on stocks, habitats and ecosystems, with associated socio-economic effects. For this reason alone, disclosing the process involved in the operation of larger scale fisheries is relevant (Steins 2006). Furthermore, fisheries of all scales experience socio-economic and cultural impacts from overfishing, poor governance, globalisation, climate change and from ocean grabbing (Barbesgaard 2018; Bavinck et al. 2018; James et al. 2015), a phenomenon that is now moving from the coast towards offshore areas (Steins 2006). Most fishers are proud of their profession and their knowledge of the sea and many come from fishing families dating back generations. Their identity and that of the communities they come from is derived from fishing. This is not only the case for fishers who own their own vessels, whatever size, but also for fishers who are crew members, no matter if they work on small coastal vessel that goes out for a day's fishing or on a super trawler.

The huge challenges fisheries all over the world are now facing in relation to climate change, ecosystem degradation and the further development of the blue economy are nondiscriminatory in terms of scale in relation to how they affect identity, livelihoods, communities, heritage and resilience. We do not find a dichotomy between small scale and large scale to be particularly useful; in fact, it has the risk of caricaturising fisheries (e.g. 'big is bad and small is beautiful') and of drawing attention away from areas where fisheries social science could have an important role to play. This is not to say that using categories is not helpful. As Johnson (Johnson 2006) points out, categorisation of fisheries helps us to reflect on how categories are constructed, used and valued. It also aids analysis of impacts on and from fisheries at local, regional and global level, and interactions between different fisheries and between different fisheries and other marine users and interests. We would therefore welcome further work on developing categorisations. This would facilitate further work on smaller scale fisheries in the Global North, which contrary to the south has received less attention, as well as research into larger scale fisheries in the Global South including distant water fleets, which has been underexposed altogether in marine social sciences (cf. Commentary 8). It would also facilitate much needed research into socio-ecological interactions, including mutual dependencies, between different type of fisheries and their value chains, into the roles fisheries in all their diversity play in securing livelihoods, providing food and preserving cultural heritage, and into the effects of different coping strategies in response to changes. Fostering diversity is an essential element of resilient fisheries and fishing and coastal communities. The role social sciences have is to study fisheries in all their different shapes, and improve our understanding of what shapes, drives and affects them and their responses to contextual changes. Such knowledge is much needed to aid decision-making on fair and sustainable fisheries and marine governance.

Open Access This article is licensed under a Creative Commons Attribution 4.0 International License, which permits use, sharing, adaptation, distribution and reproduction in any medium or format, as long as you give appropriate credit to the original author(s) and the source, provide a link to the Creative Commons licence, and indicate if changes were made. The images or other third party material in this article are included in the article's Creative Commons licence, unless indicated otherwise in a credit line to the material. If material is not included in the article's Creative Commons licence and your intended use is not permitted by statutory regulation or exceeds the permitted use, you will need to obtain permission directly from the copyright holder. To view a copy of this licence, visit http://creativecommons.org/licenses/by/4.0/.

\section{References}

Arbo, P., M. Knol, S. Linke, and K. St. Martin. 2018. The transformation of the oceans and the future of marine social science. Maritime Studies 17 (3): 295-304. https://doi.org/10.1007/s40152-018-0117-5.

Barbesgaard, M. 2018. Blue growth: savior or ocean grabbing? The Journal of Peasant Studies 45 (1): 130-149. https://doi.org/10. 1080/03066150.2017.1377186.

Bavinck, M., F. Berkes, A. Charles, A.C.E. Dias, N. Doubleday, P. Nayak, and M. Sowman. 2017. The impact of coastal grabbing on 
community conservation-a global reconnaissance. Maritime Studies 16 (1). https://doi.org/10.1186/s40152-017-0062-8.

Bavinck, M., S. Jentoft, and J. Scholtens. 2018. Fisheries as social struggle: a reinvigorated social science research agenda. Marine Policy 94 (May): 46-52. https://doi.org/10.1016/j.marpol.2018.04.026.

Hegland, T., K. Ounanian, and J. Raakjær. 2012. Why and how to regionalise the Common Fisheries Policy. Maritime Studies 11 (1): 1-21. https://doi.org/10.1186/2212-9790-11-7.

James, N.J., H. Govan, and T. Satter. 2015. Ocean grabbing. Marine Policy 57: 61-68. https://doi.org/10.1016/j.marpol.2015.03.026.

Jentoft, S., and M. Knol. 2014. Marine spatial planning: risk or opportunity for fisheries in the North Sea? MAST 12 (13): 1-16.

Johnson, D.S. 2006. Category, narrative, and value in the governance of small-scale fisheries. Marine Policy 30: 747-756. https://doi.org/10. 1016/j.marpol.2006.01.002.

Kraan, M., A. Hendriksen, L. van Hoof, J. van Leeuwen, and C. Jouanneau. 2014. How to dance? The tango of stakeholder involvement in marine governance research. Marine Policy 50: 347-352. https://doi.org/10.1016/j.marpol.2014.05.010.

Marschke, M., and P. Vandergeest. 2016. Slavery scandals: unpacking labour challenges and policy responses within the off-shore fisheries sector. Marine Policy 68: 39-46. https://doi.org/10.1016/j.marpol. 2016.02.009.

Mulazzani, L., and G. Malorgio. 2017. Blue growth and ecosystem services. Marine Policy 85 (August): 17-24. https://doi.org/10.1016/j. marpol.2017.08.006

Rice, J.C. 2011. Advocacy science and fisheries decision-making. ICES Journal of Marine Science 68 (10): 2007-2012.

Röckmann, C., J. van Leeuwen, D. Goldsborough, M. Kraan, and G. Piet. 2015. The interaction triangle as a tool for understanding stakeholder interactions in marine ecosystem based management. Marine Policy 52: 155-162. https://doi.org/10.1016/j.marpol.2014.10.019.

Schadeberg, A., Kraan, M., Hamon, K., Poos, J. J., \& Batsleer, J. (2019). Beyond metier analysis: using fishing styles to understand social heterogeneity in the Dutch demersal fleet. Presentation at the ICES Annual Science Conference, Gothenburg, September. https:// www.wur.nl/upload_mm/d/5/0/1 fa45bce-303a-4b5c-b79d2b22ae9d701c_2019Amanda ICES_NL notities.pdf

Sievanen, L., R.L. Gruby, and L.M. Campbell. 2013. Fixing marine governance in Fiji? The new scalar narrative of ecosystem-based management. Global Environmental Change 23 (1): 206-216. https:// doi.org/10.1016/j.gloenvcha.2012.10.004.

Stange, K. 2017. Knowledge production at boundaries: an inquiry into collaborations to make management plans for European fisheries. Wageningen University and Research. https://doi.org/10.18174/ 402072 .
Steins, N.A. 2006. Interactive approaches to global and local fisheries management: a challenge for fisheries social scientists. MAST 4 (2): $29-31$

Steins, N.A., M.L. Kraan, K.J. van der Reijden, F.J. Quirijns, W. van Broekhoven, and J.J. Poos. 2019. Integrating collaborative research in marine science: Recommendations from an evaluation of evolving science-industry partnerships in Dutch demersal fisheries. Fish and Fisheries, November 2019: 146-161. https://doi.org/10.1111/ faf. 12423.

Stephenson, R.L., S. Paul, M.A. Pastoors, M. Kraan, P. Holm, M. Wiber, S. Mackinson, D.J. Dankel, K. Brooks, and A. Benson. 2016. Marine Science. ICES Journal of Marine Science. 73: 1459-1465. https://doi.org/10.1093/icesjms/fsw025.

Symes, D., and E. Hoefnagel. 2010. Fisheries policy, research and the social sciences in Europe: challenges for the 21st century. Marine Policy 34 (2): 268-275. https://doi.org/10.1016/j.marpol.2009.07. 006.

Symes, D., J. Philipson, J. Raakjaer, and N.A. Steins. 2019. The European Social Science Fisheries Network (1996-1999): a formative period for marine social sciences. Marine Social Sciences Newsletter.

Toonen, H.M., and S.R. Bush. 2018. The digital frontiers of fisheries governance: fish attraction devices, drones and satellites. Journal of Environmental Policy and Planning 22: 1-13. https://doi.org/ 10.1080/1523908X.2018.1461084.

Urquhart, J., T. Acott, M. Reed, and P. Courtney. 2011. Setting an agenda for social science research in fisheries policy in Northern Europe. Fisheries Research 108 (2-3): 240-247. https://doi.org/10.1016/j. fishres.2010.12.026.

Van Helmond, A.T.M., C. Chen, B.K. Trapman, M. Kraan, and J.J. Poos. 2016. Changes in fishing behaviour of two fleets under fully documented catch quota management: same rules, different outcomes. Marine Policy 67: 118-129. https://doi.org/10.1016/j.marpol.2016. 01.029 .

Van Helmond, A.T.M., L.O. Mortensen, K.S. Plet-Hansen, C. Ulrich, C.L. Needle, D. Oesterwind, L. Kindt-Larsen, T. Catchpole, S. Mangi, C. Zimmermann, H.J. Olesen, N. Bailey, H. Bergsson, J. Dalskov, J. Elson, M. Hosken, L. Peterson, H. McElderry, J. Ruiz, J.P. Pierre, C. Dykstra, and J.J. Poos. 2019. Electronic monitoring in fisheries: Lessons from global experiences and future opportunities. Fish and Fisheries, November 2019: 162-189. https://doi.org/10. $1111 /$ faf.12425

Publisher's note Springer Nature remains neutral with regard to jurisdictional claims in published maps and institutional affiliations. 